Електронне наукове фахове видання "Ефективна економіка" включено до переліку наукових фахових видань України з питань економіки

(Категорія «Б», Наказ Міністерства освіти і науки України від 11.07.2019 № 975) www. economy.nayka.com. ua | № 3,2020| 26.03.2020 p.

DOI: $\underline{10.32702 / 2307-2105-2020.3 .156}$

CDC 338.121

T. V. But

Student of Economic Sciences Faculty, Petro Mohyla Black Sea National University.

ORCID: 0000-0002-6252-6687

K. L. Netudyhata

Candidate of Economic Science, Associate Professor of Management Cathedra,

Petro Mohyla Black Sea National University.

ORCID: 0000-0002-5322-4986

\title{
ANALYSIS OF THE FINANCIAL SUSTAINABILITY OF ENTERPRISES IN MODERN CONDITIONS
}

\author{
T. B. Буm, \\ студентка факультету економічних наук, \\ Чорноморський наиіональний університет імені Петра Могили \\ К. Л. Нетудихата, \\ к.е.н., доцент, доцент кафедри менеджменту, \\ Чорноморський наиіональний університет імені Петра Могили, м. Миколаїв
}

\section{АНАЛІЗ ФІНАНСОВОЇ СТІЙКОСТІ ПІДПРИЕМСТВ У СУЧАСНИХ УМОВАХ}

The article investigates the concept of financial stability, reveals the basic methodological methods of assessing the financial condition in general and financial stability, analyzed the financial stability of enterprises, identified the weakening of the financial condition of the company and suggested ways to improve it.

In modern conditions of management, especially in the conditions of financial crises and sociopolitical instability are challenging for businesses sustainable and efficient operation.

However, it is not only the impact of environmental factors that is negative affects the activity of enterprises, but also the lack of an effective mechanism for managing financial security and ensuring an adequate level of financial sustainability for businesses that can withstand permanent one changes in economic conditions. Identification of the main components of the financial management mechanism enterprise sustainability is one of the most important and pressing problems today, whereas lack of financial stability can lead to the insolvency of an enterprise, destruction of strategic potential and threats to its financial security. The condition of sustainable development of the enterprise as a whole is its effective economic activity, is aimed at ensuring one's own survival, stability, development and achievement of its stated goals. One of the main factors for sustainable enterprise development should be a mechanism that would monitored the accomplishment of the set tasks in the long run.

The need to develop theoretical approaches to the study of financial stability is to ensure the stabilization of the financial position of enterprises based on the use of strategic and tactical financial management tools. The formation of an effective strategy for overcoming the insolvency of economic entities is determined by the prospects for the development of financial management, rethinking the results of previous development, changing the quality of monitoring the financial 
condition of enterprises, developing algorithms for crisis diagnosis, minimizing financial risks and rational management of financial flows.

У статті досліджено поняття фінансової стабільності, розкрито основні методологічні методи оцінки фінансового стану загалом та фінансової стійкості, проаналізовано фінансову стійкість підприємств, виявлено ослаблення фінансового стану підприємства та запропоновано шляхи його покращення.

У сучасних умовах управління, особливо в умовах фінансових криз та соціально-політичної нестабільності, є складною для бізнесу стабільна та ефективна діяльність.

Однак не тільки вплив факторів навколишнього середовища негативно впливає на діяльність підприємств, а й відсутність ефективного механізму управління фінансовою безпекою та забезпечення належного рівня фінансової стійкості для бізнесу, який може протистояти постійним змінам економічних умови. Визначення основних складових механізму фінансового управління стійкістю підприємства є однією з найважливіших та найактуальніших проблем сьогодні, тоді як відсутність фінансової стабільності може призвести до неплатоспроможності підприємства, руйнування стратегічного потенціалу та загрози його фінансовій безпеиі. Умовою сталого розвитку підприємства в ичілому є його ефективна економічна діяльність, спрямована на забезпечення власного виживання, стабільності, розвитку та досягнення поставлених иілей. Одним із основних факторів сталого розвитку підприємства повинен стати механізм, який би моніторив виконання поставлених завдань у довгостроковій перспективі.

Потреба в розробиі теоретичних підходів щзодо дослідження фінансової стійкості полягає в забезпеченні стабілізащіі фінансового стану підприємств, заснованої на використанні інструментів стратегічного $i$ тактичного фінансового менеджменту. Формування ефективної стратегї з подолання неплатоспроможності суб'єктів господарювання визначається перспективами розвитку фінансового менеджменту, переосмисленням підсумків попереднього розвитку, зміною якості моніторингу фінансового стану підприємств, розробкою алгоритмів діагностики кризових явищ, мінімізацією фінансових ризиків і раціональним управлінням фінансовими потоками.

Keywords: stability; financial stability; analysis of financial stability of an enterprise; coefficients of financial stability; indicators of financial stability.

Ключові слова: стабільність; фінансова стійкість; аналіз фінансової стійкості підприємства; коефіцієнти фінансової стійкості; показники фінансової стійкості.

Problem statement. Financial stability of the enterprise is one of the main conditions for the vital activity, development and ensuring a high level of competitiveness of the enterprise. It is the financial stability of the enterprise that characterizes the effectiveness of operational, investment and financial development, contains the necessary information for investors, as well as reflects the ability of the company to answer for its debts and obligations. As practice shows, financially sound enterprises have advantages over other enterprises in the same industry in attracting investments, in choosing suppliers, in the selection of qualified personnel. In addition, they do not conflict with the state on the transfer of taxes and non-tax payments and with the public - on payment of wages and dividends.

Analysis of recent research and publications. Theoretical foundations and practical methods of ensuring the financial stability of enterprises are reflected in the works of domestic and foreign scientists, in particular: V.K. Bansal, R.A. Chemchikalenko, L.A. Costirko, K. Drury, A.S. Linova, J.F. Marshall, O.V. Mayboroda, S.Z. Moshensky, T.A. Obushchak, O.V. Oliynyk, M.V. Savchenko, A.G. Semenov, O.V. Shkurenko and other scientists. The available results of scientific theories have not been reflected in a single logically constructed approach, which allows to study changes in financial stability under the influence of internal and external factors and to identify the prospects of its provision with financial management tools.

Purpose of research. The purpose of the article is to study the economic nature of financial stability and to study the impact of a system of factors on the financial sustainability of enterprises in the current operating conditions.

Research outcomes. One of the most important characteristics of a company's financial position is its financial stability (stability). Financial stability is a securely guaranteed solvency, equilibrium between own and borrowed funds, independence from contingencies of market conditions and partners, trust of creditors and investors and the level of 
dependence on them, availability of such amount of profit that would provide self-financing.

A system of indicators that are used in the domestic and world practice to assess the financial stability of the enterprise is developed. The main ones are:

- coefficient of concentration of own capital (coefficient of autonomy);

- coefficient of financial dependence;

- coefficient of maneuverability of own capital;

- ratio of working capital to own working capital;

Today, in the economy, there are many points of view on the definition of the concept of "financial sustainability", which have common features or significant differences [10, p. 380]. This term is used at all levels from individual households or sole proprietors to the activities of the global financial systems. Some scholars characterize financial sustainability as long-term solvency. Others say it is the optimal structure and composition of current assets. A third group of scientists believes that it is a stable activity of the enterprise in the long term, which is determined by the ratio of equity and debt and its effective use. Such a diversity of approaches to determining the financial soundness of an enterprise certainly testifies to the versatility of the concept.

T.A. Obushchak defines the financial condition of the enterprise as an essential characteristic activity of enterprises in a certain period, which determines the real and potential ability of the enterprise to provide a sufficient level of financing of financial and economic activities and the ability to effectively carry out these activities in the future [6, p. 92].

S.Z. Moshensky and O.V. Oliynyk, considering the essence of financial stability, determine the main prerequisite for its compliance with the conditions of financial equilibrium between own and borrowed sources [4, $\mathrm{p}$. 82].

K. Drury proposes to evaluate the financial stability of an enterprise through its financial independence, which is related to the overall structure of the enterprise, the degree of dependence on external sources of financing [1, p. 113].

An interesting approach, in our opinion, is the approach to determining the financial stability of the company by representatives of the American School of Management, J. F. Marshall and V. K. Bansal. They consider financial innovations and trends that act as external factors and conditions for the stability of the enterprise. In their view, new financial products should guide forecasting the expected values of financial performance and the permissible ranges of their error [3, p. 36].

L.A. Costirko discloses financial stability as an integral characteristic of an enterprise's ability to transform financial resources with maximum economic benefit and minimal risk [2, p. 123].

A.G. Semenov defines the financial stability as a complex concept that characterizes a stable financial position in an enterprise, in which there is an efficient allocation, formation and use of financial resources that ensures profitability, solvency and development of long-term activity [9, p. 120].

In our opinion, financial sustainability should mean the ability of an enterprise to finance its operations on an expanded basis, to resist the perturbation of an unstable external environment, and to maintain its solvency in adverse circumstances [5, p. 168].

One of the important components of financial sustainability is the availability of the necessary amount of financial resources that can be formed only if the enterprise is working efficiently and making a profit, which is impossible without the use of management decisions.

The financial stability of enterprises is significantly influenced by the phase of the economic cycle in which the state's economy is located. In times of crisis, there is a lag in the pace of sales of products than the rate of production, which is observed today in Ukraine. Investment in inventory decreases, further reducing sales. Also, the income of business entities decreases, as do the profits. All this leads to a decrease in the liquidity of enterprises, their solvency and creates preconditions for mass bankruptcies.

The analysis of the composition and placement of assets of an economic entity is performed on the basis of the table of comparative-analytical balance by asset items using methods of vertical (structural) and horizontal (dynamic) analysis.

Achieving a sound financial position is possible with sufficient equity, with efficient use of assets, with a sufficient level of profitability taking into account operational and financial risks, with sufficient liquidity, stable income and broad borrowing facilities. In order to ensure financial stability, the enterprise must have a flexible capital structure, the ability to organize its movement in such a way as to ensure a constant excess of income over costs in order to maintain solvency and create conditions for self-financing.

The stability of the financial condition of the enterprise depends on the optimal structure of sources of capital (on the ratio of equity and borrowed funds), on the structure of assets of the enterprise and above all on the ratio of fixed and current assets, as well as on the balance of assets and liabilities of the enterprise on a functional basis.

The financial sustainability of an enterprise is its ability to withstand, resist and adapt to the effects of exogenous and endogenous factors [8, p. 97]. Many scholars agree that financial sustainability is a property of an enterprise that reflects in the process of interaction of external and internal factors the achievement of the state of financial equilibrium and its ability to develop. From this definition it clearly follows that the financial stability of the company is influenced by external and internal factors, the degree of influence of which depends on the financial market conditions and changes in the economic and political situation in the country.

The management of the enterprise should react quickly to the constraints created by the system of economic relations, maneuvering financial resources and production programs. It is necessary to "develop immunity" to the 
influence of external and internal factors that violate the reproductive activity of the enterprise.

Financial decisions made by business leaders are influenced by external factors such as: the state of the economy; financial policy of the state; legislative and regulatory framework; state financial regulation; actions of competitors; supplier actions and consumer behavior; actions of financial intermediaries; actions of investors; the level of socio-cultural development; social, cultural and environmental factors. The composition of internal factors is determined by the internal environment of economic entities and is determined by their production, financial and economic, human resources, technological support, the results obtained.

The financial support of the enterprise requires constant management in order to achieve the optimum composition and structure of its sources. An indispensable step in this management is to determine the state of financial security, which should be closely linked to the diagnosis of economic performance of the enterprise. The effectiveness of this process depends largely on the further production and economic activity of the enterprise, since the lack of financial resources can almost completely paralyze the entire activity of the entity.

In modern conditions, the structure of capital is the factor that has a direct impact on the financial condition of the enterprise - its solvency and liquidity, income, profitability. Equity is the basis of activity of each enterprise, therefore timely and complete analysis of it allows to receive new characteristics of the object and to apply the sound management decision leading to achievement of the purpose of activity of the enterprise.

Analysis of the capital of the enterprise involves determining the assessment of the composition of capital and its structure, changes in the components of capital and sources of formation. Based on the aggregate balance sheet (statement of financial position), we will analyze the capital formation of the PJSC "Volyn Bakery" for 2016-2018 (Table 1).

Table 1.

Analysis of the composition, dynamics and capital structure of the enterprise for 2016-2018

\begin{tabular}{|c|c|c|c|c|c|c|c|c|}
\hline \multirow[t]{2}{*}{ Indexes } & \multicolumn{3}{|c|}{ Volume, thousand UAH } & \multicolumn{3}{|c|}{ Specific weight, $\%$} & \multicolumn{2}{|c|}{$\begin{array}{c}\text { Absolute } \\
\text { deviation, } \\
\text { thousand UAH }\end{array}$} \\
\hline & 2016 & 2017 & 2018 & 2016 & 2017 & 2018 & $\begin{array}{c}2017- \\
2016 \\
\end{array}$ & $\begin{array}{c}2018- \\
2017 \\
\end{array}$ \\
\hline \multicolumn{9}{|c|}{ Fixed and working capital } \\
\hline Non-current assets & 6117 & 6351 & 6926 & 57.6 & 61.0 & 48.3 & 234 & 575 \\
\hline Current assets, including & 4508 & 4060 & 7417 & 42.4 & 39.0 & 51.7 & -448 & 3357 \\
\hline Current assets & 1157 & 1780 & 2171 & 10.9 & 17.1 & 15.1 & 623 & 391 \\
\hline Liquid assets: & 3339 & 2256 & 5239 & 31.4 & 21.7 & 36.5 & -1083 & 2983 \\
\hline - receivables & 1620 & 2222 & 3167 & 15.2 & 21.3 & 22.1 & 602 & 945 \\
\hline -cash and cash equivalents & 1719 & 34 & 2072 & 16.2 & 3.4 & 14.4 & -1685 & 2038 \\
\hline Other current assets & 12 & 24 & 7 & 0.1 & 0.2 & 0.1 & 12 & -17 \\
\hline \multicolumn{9}{|c|}{ Sources of capital formation } \\
\hline Equity & 7654 & 7301 & 11013 & 72.0 & 70.1 & 76.8 & -353 & 3712 \\
\hline Debt capital, including: & 2971 & 3110 & 3330 & 28.0 & 29.9 & 23.2 & 139 & 220 \\
\hline $\begin{array}{l}\text { Long-term commitment and } \\
\text { security }\end{array}$ & 328 & 120 & 0 & 3.1 & 1.2 & 0.0 & -208 & -120 \\
\hline $\begin{array}{l}\text { Current commitments and } \\
\text { assurances: }\end{array}$ & 2643 & 2990 & 3330 & 24.9 & 28.7 & 23.2 & 347 & 340 \\
\hline - lend to the bank & 0 & 805 & 0 & 0.0 & 7.7 & 0.0 & 805 & -805 \\
\hline -current accounts payable & 2560 & 2051 & 2650 & 24.1 & 19.7 & 18.5 & -509 & 599 \\
\hline -current security & 36 & 72 & 437 & 0.3 & 0.7 & 3.0 & 36 & 365 \\
\hline - other current commitments & 47 & 62 & 243 & 0.5 & 0.6 & 1.7 & 15 & 181 \\
\hline Balance currency & 10625 & 10411 & 14343 & 100.0 & 100.0 & 100.0 & -214 & 3932 \\
\hline
\end{tabular}

Source: compiled by the authors based on [7]

Having studied the sources of capital formation of the enterprise and the directions of its placement according to the Table 1 shows that the total amount of capital of the enterprise during the whole analyzed period tends to increase in 2018 compared to 2016 by 3718 thousand UAH, although in 2017 there is a noticeable decrease of the total capital by 214 thousand UAH vs. 2016.

Such growth during the analyzed period was mainly due to a significant increase in equity, which was ahead of the growth of borrowed funds: in 2018 compared to 2016, equity increased by 3359 thousand UAH. (43.9\%), in 2017 compared to 2016 decreased by 353 thousand UAH (4.6\%), in 2018 there is an increase of 3712 thousand UAH $(50.8 \%)$ against the previous year.

Non-current assets account for the largest share of the company's property during 2016-2017, but their share tends to fluctuate, namely: in 2017 versus 2016 , the share of non-current assets is growing from $57.8 \%$ to $61.0 \%$, in 2016 their share decreased by $12.7 \%$ to $48.3 \%$. The opposite dynamic is characteristic of current assets.

The following changes are noticeable in the composition of current assets. During the analyzed period, current 
assets, namely stocks, also exhibited an unstable tendency, namely: in 2017 their volume is growing by 623 thousand UAH in comparison with the previous year, and in 2018 - their volume growth at a slower rate - by 391 thousand UAH against 2017. At the same time, for the whole analyzed period their total value increased by 1014 thousand UAH. However, in the structure of current assets the share of current assets increased in 2016-2017 from $10.9 \%$ to $17.1 \%$, and in 2018 amounted to $15.1 \%$.

During 2016-2018, the largest share in the structure of current assets was represented by liquid assets, whose share in 2017 decreased by $9.7 \%$, in 2018 it increased by $14.8 \%$ and amounted to $36.5 \%$. At the same time, a similar situation is observed in the dynamics of their absolute volume, namely: in 2017, the volume of liquid assets decreases by 1083 thousand UAH, and in 2018 increases by 2983 thousand UAH.

Among liquid assets, the largest share is accounted for by receivables of $15.2 \%$ as of 2016 and by the end of 2018 it will increase by 6.9 points and amounted to $22.1 \%$. At the same time, a study of the dynamics of changes in accounts receivable shows that in 2017 its volume increased by 602 thousand UAH against 2016, and in 2018 - by 945 thousand UAH. In general, an increase in the amount of receivables at the enterprise is a negative phenomenon, as it indicates a failure to comply with the contractual and settlement discipline and late filing of debt claims at the enterprise. Positive is the increase of the share of cash and cash equivalents in the structure of liquid assets in 2018 by $11 \%$, which indicates an increase in liquidity of the company.

In further analysis, it is necessary to study the dynamics and structure of equity and debt capital, to find out the reasons for changes in its individual components and to evaluate these changes for the analyzed period.

The financial basis of the enterprise is its own capital. It is the initial and indefinite basis of financing the activity of the enterprise, as well as a source of repayment of its losses, one of the most important indicators used in assessing the financial condition of the enterprise, because it shows: on the one hand, the degree of financial independence of the enterprise (its independence from external sources of financing); on the other - the degree of creditworthiness of the enterprise (ensuring the requirements of creditors available in the enterprise capital of the founders).

In order to study the reasons for the change in the size and composition of equity for the period, we draw up and consider the analytical Table 2.

Table 2.

Analysis of the main articles of equity of the enterprise

\begin{tabular}{|l|c|c|c|c|c|}
\hline \multirow{2}{*}{\begin{tabular}{l}
\multirow{2}{*}{ Indexes } \\
\cline { 2 - 6 }
\end{tabular}} & \multicolumn{2}{c|}{ Volume, thousand UAH } & \multicolumn{2}{c|}{$\begin{array}{c}\text { Absolute deviation, } \\
\text { thousand UAH }\end{array}$} \\
\cline { 2 - 6 } & 2016 & 2017 & 2018 & $2017-2016$ & $2018-2017$ \\
\hline Equity & 7654 & 7301 & 11013 & -353 & 3712 \\
\hline \% to total & 100.0 & 100.0 & 100.0 & 0 & 0 \\
\hline including: & & & & & \\
\hline - registered capital & 775 & 775 & 775 & 0 & 0 \\
\hline \% to total & 10.1 & 10.6 & 7.0 & 0.5 & -3.6 \\
\hline - reserve capital & 227 & 227 & 227 & 0 & 0 \\
\hline \% to total & 3.0 & 3.1 & 2.1 & 0.1 & -1.0 \\
\hline - allocated profit & 6652 & 6299 & 10011 & -353 & 3712 \\
\hline \% to total & 86.9 & 86.3 & 90.0 & -0.6 & 3.7 \\
\hline
\end{tabular}

Source: compiled by the authors based on [7]

According to the Table 2 the size of the registered (unit) capital, which is reflected in the financial statements of the enterprise, corresponds to the size specified in the charter of the enterprise and makes 775 thousand UAH and remains unchanged during the study period.

The reserve capital of the enterprise remained unchanged during the analyzed period and amounted to 227 thousand UAH.

The article retained earnings reflects the amount of profit reinvested in the business. The amount of retained earnings during 2016-2017 has an unstable tendency to decrease, in particular: in 2017, there is a decrease by 353 thousand UAH, in 2018 its volume increases by 3712 thousand UAH.

The largest share in the structure of the equity of the enterprise in 2016-2018 is retained earnings, the share of which fluctuates similarly to the dynamics of volumes and makes $86.9 \%, 86.3 \%$ and $90.0 \%$ respectively, considering the constant volumes of other components of the own capital.

Any business requires borrowing capital for its operations if there are no own funds. Borrowings occupy a considerable place in the capital structure of the enterprise. The use of borrowed capital allows to expand the volume of business activity of the enterprise, to ensure more efficient use of equity capital, to accelerate the formation of various financial funds, and ultimately - to increase the market value of the enterprise. However, there is also a negative impact of borrowing, namely the decrease in profitability, liquidity, business activity and deterioration of the financial condition of the enterprise as a whole.

Along with the absolute (general) indicators financial stability of the enterprise is also characterized by financial ratios. They are calculated as the ratio of absolute assets to liabilities of the balance sheet. In the Table 3 shows the calculation of partial indicators of financial stability of the enterprise. 
Table 3.

Indicators of financial stability of the enterprise for the period from 2016 to 2018

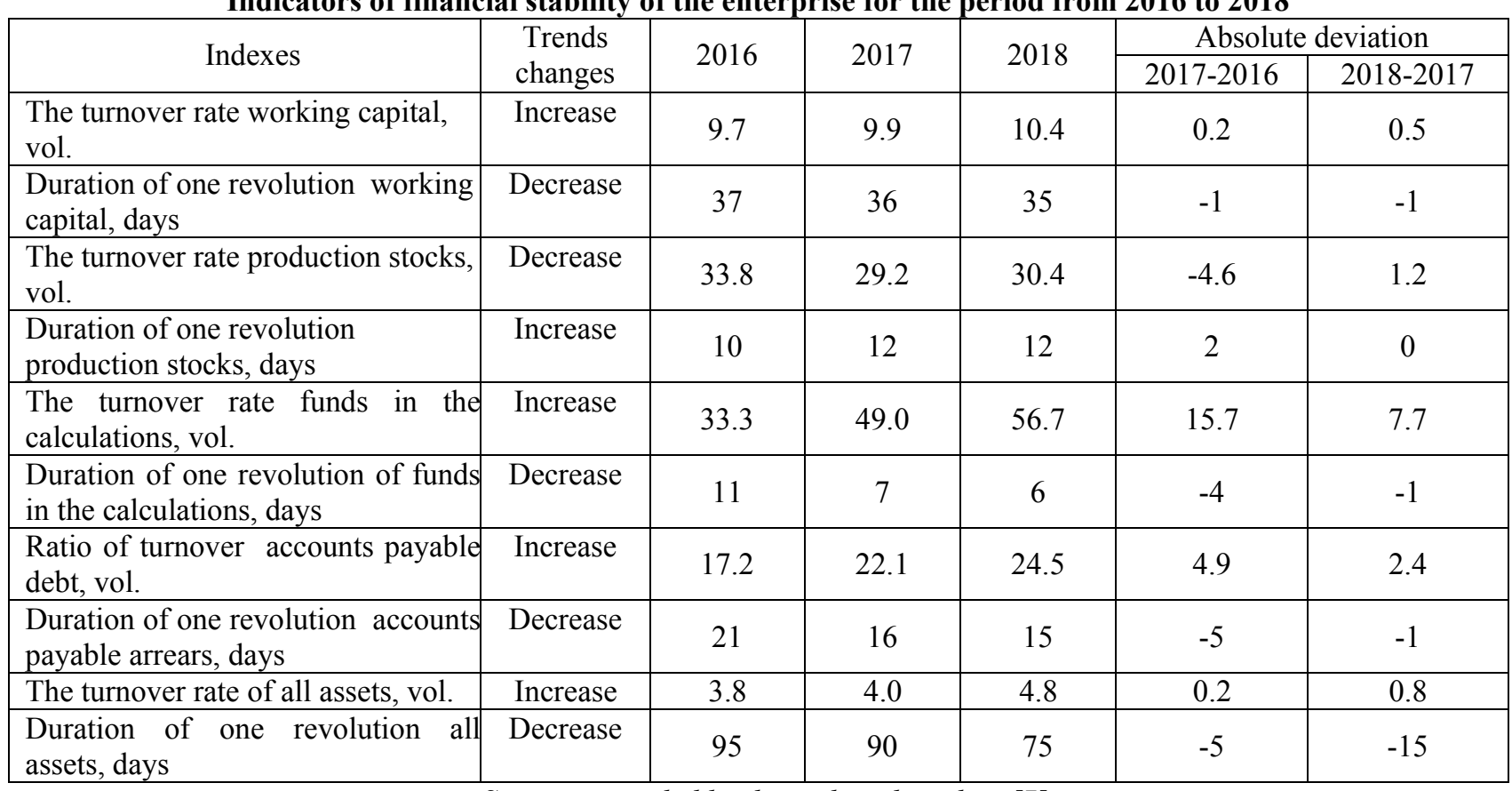

Source: compiled by the authors based on [7]

However, compared to 2016, it is observed almost all indicators show improvement, that is, improvement in payment discipline at the enterprise. This is evidenced by the reduced duration of rotation of all types of assets of the enterprise.

By analyzing the coefficients, you can identify the strengths and weaknesses of the company. Managers use this data to control the activities of an enterprise to prevent bankruptcy. Also important is the fact that the coefficient analysis allows you to better understand the relationship between the balance sheet and the income statement. The analysis of the relative indicators of the enterprise are given in Table 4.

Table 4.

Analysis of relative indicators of financial stability of the enterprise

\begin{tabular}{|l|c|c|c|c|}
\hline \multicolumn{1}{|c|}{ Indicator } & 2018 & Forecast period & $\begin{array}{c}\text { Absolute } \\
\text { deviation }\end{array}$ & $\begin{array}{c}\text { Recommended } \\
\text { value }\end{array}$ \\
\hline $\begin{array}{l}\text { Ratio of provision of circulating assets } \\
\text { own funds }\end{array}$ & 0.5 & 0.55 & -0.05 & $>0.5$ \\
\hline Inventory ratio own funds & 1.9 & 1.9 & 0.0 & $>0.8$ \\
\hline The coefficient of real value fixed assets & -0.15 & 0.4 & -0.55 & $0.3-0.5$ \\
\hline $\begin{array}{l}\text { The coefficient of real value fixed assets } \\
\text { and inventories }\end{array}$ & 0.45 & 0.76 & -0.31 & 0.8 \\
\hline Maneuverability factor of own Capital & 0.37 & 0.5 & -0.13 & $>0.5$ \\
\hline Long-term ratio borrowing & 0.0 & 0.0 & 0.0 & Reduction \\
\hline Mobility rate & 1.1 & 0.5 & 0.6 & $>0.5$ \\
\hline Fixed Assets Index & 0.63 & 0.5 & 0.13 & Decrease \\
\hline Financial independence ratio & 0.77 & 0.8 & -0.03 & $>0.5$ \\
\hline Financial risk ratio & 0.3 & 0.2 & 0.1 & $<0.2$ \\
\hline Debt concentration ratio capital & 0.23 & 0.2 & 0.03 & $<1.0$ \\
\hline Investment rate & 1.6 & 1.6 & 0.0 & - \\
\hline
\end{tabular}

Source: compiled by the authors based on [7]

Based on the analysis (Table 4), such indicators as the long-term borrowing ratio, which in 2018 is 0 compared to previous periods, tend to improve. The mobility factor also exceeds the recommended value of 0.5 during the analyzed period is 1.1 .

The coefficients of financial dependence also showed good results in 2018 and indicates a decrease in the degree of dependence of the enterprise on external creditors. At the same time, the coefficient of real value of fixed assets is negative and does not reach the recommended value, which should be addressed to the management of PJSC 


\section{"Volyn Bakery".}

Therefore, the analysis showed that, mainly, during 2016-2017, the company has deteriorated financial stability. At the same time, in 2018 compared to 2016, the opposite trend is being followed, in which all indicators of financial sustainability are improving. Management's actions should be aimed at improving financial sustainability and reducing the degree of financial risk.

Conclusions. Therefore, financial stability is one of the most important characteristics of financial and economic activity of an enterprise in a market economy. If a company is financially sound, it has an advantage over other businesses of the same profile in attracting investments, in obtaining loans, in selecting suppliers and in the selection of qualified personnel. Finally, it does not conflict with the state and society, because it pays taxes on the budget, contributions to social funds, wages, and guarantees banks repayment of loans and interest payments on them. Thus, the given sequence of stages of implementation of the mechanism of financial stability management is effective and can be applied in real economic conditions.

In the conditions of difficult financial and economic situation in Ukraine, which is connected with external global problems and internal difficult socio-economic situation, it is necessary for enterprises to take all possible measures to stabilize financial economic activity. To this end, it is advisable to recommend:

- to carry out constant monitoring and operational analysis of indicators of the financial condition of the enterprise, taking into account the industry characteristics;

- improve and stabilize financial and tax legislation;

- to provide the possibility of using preferential credits for the enterprises of the agro-industrial sector;

- improve information and methodological support for analysis and forms of financial reporting, which will increase the analytical capabilities and the reality of property valuation;

- to adapt foreign methods of analysis of financial condition to the practice of management of subjects of national economy;

- use not only retrospective but also prospective analysis of financial position on the basis of projected (forecasted) forms of financial statements.

The application of the proposed analysis methodology and the system of financial stability indicators will allow, based on the goals and objectives of the analysis, to select, prepare and evaluate the available information, justify the application of accounting and analytical procedures and methods of analysis, to conduct a comparative assessment of the level of financial independence of enterprises. All this will to some extent contribute to the rational construction of a functional system of relationships for the analysis, improving its quality and efficiency.

One of the identified tasks today is to ensure the relative financial equilibrium of an enterprise in the process of its development. Such equilibrium is characterized by high level of financial stability and solvency of the enterprise and is provided by formation of rational structure of property and capital, effective proportions in the volumes of formation of financial resources at the expense of various sources, sufficient level of self-financing of investment needs. The formation of a mechanism for managing financial stability will allow managers to use it to ensure the stable functioning and forecast the future development of the enterprise.

Thus, with the improvement of the financial and economic mechanism for managing the activity of the enterprise, it will be possible to achieve the long-term goals of both the enterprise and the state, as well as to stabilize the national economy and increase the level of competitiveness of the national economy in the world market.

\section{References.}

1. Drury, K. (2015), Proyzvodstvennyj y upravlencheskyj uchiot [Production and management accounting], YuNYTY, Moskva, Russia.

2. Kostyrko, L. A. (2015), “Analysis of financial potential in the enterprise value management system”, Visnyk Skhidnoukrains'koho natsional'noho universytetu im. V. Dalia, vol. 4(221), pp. 122-130.

3. Marshall, Dzh. F., Banksal, V.K. (1998), Fynansovaia ynzheneryia. Polnoe rukovodstvo po fynansovym novovvedenyiam [Financial engineering. A complete guide to financial innovation.], YNFRA-M, Moskva, Russia. Ukraine.

4. Moshens'kyj, S.Z., Olijnyk, O.V. (2007), Ekonomichnyj analiz [Economic analysis], PP "Ruta",Zhytomyr,

5. Netudykhata, K.L. (2018), "Financial stability of machine-building enterprises of Ukraine at the current stage of economic development", Infrastruktura rynku, vol. 15, pp. 167-173.

6. Obuschak, T.A. (2009), "The essence of the financial condition of the enterprise", Aktual'ni problemy ekonomiky, vol. 9, pp. 92-100.

7. Official site of the Stock Market Infrastructure Development Agencies of Ukraine (2020), available at: http://www. smida.gov.ua/ (Accessed 15 Feb. 2020).

8. Savchenko, M.V. and Shkurenko, O.V. (2019), "Financial sustainability as a prerequisite for international business development", Biznes inform, vol. 10, pp. 96-104.

9. Semenov, A.H. (2019), "Formation of a strategy for ensuring the financial stability of an industrial enterprise", Derzhava ta rehiony. Seriia: Ekonomika ta pidpryiemnytstvo, vol. 4 (109), pp. 119-125.

10. Chemchykalenko, R.A. Majboroda, O.V. and Lyn'ova, A.S. (2019), "Features of evaluation and analysis of financial stability of the enterprise", Infrastruktura rynku, vol. 32, pp. 379-385. 


\section{Література.}

2. Друри К. Производственный и управленческий учёт. Москва, ЮНИТИ, 2015. 476 с.

3. Костирко Л. А. Аналіз потенціалу фінансової в системі управління вартістю підприємства. Вісник Східноукраїнського національного університету ім. В. Даля. 2015. № 4(221). С. 122-130.

4. Маршалл Дж. Ф., Банксал В.К. Финансовая инженерия. Полное руководство по финансовым нововведениям. Москва, ИНФРА-М, 1998. 784 с.

5. Мошенський С.3., Олійник О.В. Економічний аналіз. Житомир, ПП «Рута», 2007. 704 с.

6. Нетудихата К.Л. Фінансова стійкість машинобудівних підприємств України на сучасному етапі розвитку економіки. Інфраструктура ринку. 2018. Випуск 15. С. 167-173. C. $92-100$.

7. Обущак Т.А. Сутність фінансового стану підприємства. Актуальні проблеми економіки. 2009. № 9.

8. Офіційний сайт Агентства 3 розвитку інфраструктури фондового ринку України, URL: https://smida.gov.ua

9. Савченко М.В., Шкуренко О.В. Фінансова стійкість як передумова розвитку міжнародного бізнесу. Бізнес інформ. 2019. № 10. С. 96-104.

10. Семенов А.Г. Формування стратегії забезпечення фінансової стійкості промислового підприємства. Держава та регіони. Серія: Економіка та підприємництво. 2019. № 4 (109). С. 119-125.

11. Чемчикаленко Р.А., Майборода О.В., Линьова А.С. Особливості оцінки та аналізу фінансової стійкості підприємства. Інфраструктура ринку. Випуск 32. 2019. С. 379-385.

Стаття надійшла до редакиії 20.03.2020 p. 